\title{
THE ROLE OF PRAGMATIC INFERENCING IN CAUSING SEMANTIC CHANGE
}

\author{
MARCIN GRYGIEL \\ University of Rzeszów, Poland \\ mgrygiel@poczta.fm
}

\begin{abstract}
Semantic change does not have to be viewed as a linear and historical phenomenon. Meaning is dynamic by its very nature and semantic variability can be primarily traced in synchronic pragmatic processes such as inferencing. The aim of the following study is to illustrate the thesis that without interactionally-induced and cognitively-motivated polysemy one cannot account for the fine-grained step-by-step developments that are attested by detailed analyses of texts and contexts over time. The semantic developments presented here seem to show that semantic change is embedded in larger contextual units such as sentence, text or discourse rather than being lexically-confined. From this perspective, the semantic change itself appears as a multi-directional and pragmatically conditioned meaning configuration.
\end{abstract}

KEYWORDS: diachronic semantics, cognitive linguistics, pragmatic negotiation.

\section{EL PAPEL DE LAS INFERENCIAS PRAGMÁTICAS EN EL PROCESO DE CAMBIO SEMÁNTICO}

\section{RESUMEN}

El cambio semántico no debe concebirse como un fenómeno histórico y lineal. El significado es dinámico por naturaleza y la variación semántica puede trazarse en primera instancia como un proceso pragmático sincrónico basado en inferencias. El propósito del presente estudio es ilustrar la tesis de que sin una polisemia inducida interactivamente y motivada cognitivamente no se puede llevar a cabo un análisis paso a paso de los desarrollos semánticos que se documentan gracias a análisis detallados de textos y contextos a lo largo del tiempo. Las evoluciones semánticas presentadas aquí parecen mostrar que el cambio semántico está más relacionado con unidades contextuales como la oración, el texto o el discurso que con un contenido léxico bien definido. Desde esta perspectiva, el cambio semántico se puede entender como un fenómeno multidireccional y pragmáticamente configurado.

PALABRAS CLAVE: semántica diacrónica, lingüística cognitiva, negociación pragmàtica.

\section{SEMANTIC CHANGE AS A RESUlT OF CONTEXTUALISATION AND MEANING NEGOTIATION}

In diachronic semantics, semantic change is traditionally regarded as a historical and lexically-bound process. The consequences of semantic change can be observed from the historical perspective as a linear progression of sense substitutions. We generally associate semantic change with etymology where one, remote in time, lexical meaning follows another. In reality, however, any 
change in meaning takes place at a synchronic level and its causes cannot be confined to the limits of a single lexical item. The causes of semantic change are always context-induced and cognitively motivated rather than purely linguistically encoded. Lewandowska-Tomaszczyk (1985: 300) claims that "in the course of ongoing interaction meaning is negotiated, i.e. jointly and collaboratively constructed" and this pragmatic process results in semantic variability and change. Therefore, the study of semantic change must take into consideration the pragmatic conditioning with the beliefs and inferences about the nature of the assumptions made by participants and the purposes for which utterances are used in the context of communicative language use. Unfortunately, the exact contexts of situation, in which semantic shifts occurred many years ago, may be very difficult to reconstruct.

Under this proposal, the semantic content of a lexical item is not perceived as fixed and independent of pragmatic inference; but rather, pragmatic inference determines an utterance's semantic content and results in various kinds of meaning contextualisations at the lexical level. Thus, semantic change originates as a semantic extension in the process of polysemisation and with time the ties between the core and periphery become loosened leading to a situation where a new meaning loses all associative links with the term from which it had been derived.1 As illustrated in Grygiel (2004, 2008, 2012), the whole process takes place very smoothly without abrupt leaps and demarcation lines between intermediary stages which, in fact, cannot be precisely delimited. Very often the various stages coexist at the same time as the diffusion of a change runs not only along the temporal axis but also has a spatial and social dimension of propagation. Since polysemy is typically the intermediate step in semantic change, the same regularities observable in polysemy can be extended to the analysis of semantic change.

The meaning conveyed directly by linguistic form is only a tip of an iceberg of underlying information structure that lies beneath the surface of the meaning expressed by a sentence or the so called proposition (Lambrecht 1994, Fauconnier 1997). Classic examples of this phenomenon are the indirectly conveyed presuppositions, entailments and inferences. All of them seem to rely on the commonsense reasoning of our daily existence and serve to construct the simple meanings of everyday life. They are used to create meaning that makes an impression of straightforwardly contained in language, but it fact, the actual pragmatic meaning conveyed in the act of communication, exceeds the overt information that a language form could carry. From this perspective, the

\footnotetext{
${ }^{1}$ It is important to note that for Bréal, who first introduced the term polysemy in 1897 in his fundamental Essai de sémantique, polysemy arises as a consequence of semantic change. Bréal (1897) claims that polysemy is the synchronic side of lexical semantic change and can show different facets according to the kind of semantic relation between the old sense and the new one which is derived from this older sense (see also Fritz 1998:57).
} 
phenomenon of semantic change can be understood as the gap between what is literally expressed by the linguistic form and the rich layers of understatements and connotations evoked by numerous presuppositions, entailments and other types of inferences.

\section{INFERENCES}

Pragmatic inferencing is the process of reaching a conclusion from known facts or evidence. Thus, inferences are logical conclusions based on observations and prior knowledge. They are only indirectly triggered by explicit language structures (Levinson 1983: 182). According to this definition, both presuppositions and entailments are instances of inferences. The problem of inferences in natural language has a long history, originating in the syllogisms of Aristotle and continuing through the medieval scholastics and the work of Leibniz.

Gricean theories of pragmatics posit that the interpretation of an expression is not necessarily identical to its semantic content. Rather, this semantic content plays a specific role in the derivation of the expression's interpretation. Gricean pragmatic accounts thus factor the interpretation of an expression into two parts: its semantic content, which determines its literal meaning, and cooperative social reasoning, which builds on this literal interpretation to determine the expression's inferred meaning. According to Geis (1982: 46), "human beings are 'inferencing' creatures, trained to 'read into' what is said as much as is consistent with the literal meaning of what is said and the context in which it is said". Pragmatics is thus the study of how more is communicated than is actually said. Listeners make inferences about what is linguistically expressed in order to arrive at an interpretation of the speaker's intended meaning. The choice of one type of referring expression rather than another seems to be based on what the speaker assumes the listener already knows.

In text linguistics, inferencing is connecting prior knowledge to text based information to create meaning beyond what is directly stated. Thus, It is the process of creating personal meaning from text. Inferencing involves a mental process of combining what is read with relevant prior knowledge (schema/background knowledge). As a result of inferencing, the reader's unique interpretation of text is the product of this blending (Graesser et al. 2001). When readers infer, they create a meaning that is not necessarily stated explicitly in the text. The process implies that readers actively search for, or are aware of, implicit meaning.

Another account of the phenomenon of inferencing comes from Relevance Theory (Sperber and Wilson 1986), which assumes that the interpretation of an utterance can be inferentially enriched in order to better capture the speaker's intention. Sperber and Wilson (1986) propose that verbal communication 
involves both coding and inferential processes. According to the code model, communication is achieved by encoding and decoding messages, while in the inferential model, it is achieved by producing and interpreting evidence. Inferential and decoding processes are quite different. An inferential process starts from a set of premises and results in a set of conclusions, which follow logically from, or at least warranted by, the premises. A decoding process starts from a signal and results in the recovery of a message, which is associated to the signal by an underlying code. In general, conclusions are not associated to their premises by a code, and signals do not warrant the messages they convey (Sperber and Wilson 1986: 13).

\section{INFERENCES IN SEMANTIC CHANGE}

The pragmatic approach to the study of semantic change is mainly based on Grice and NeoGricean pragmatics (Levinson 2000). To a large extent, it continues contextual and functional works from the end of the $19^{\text {th }}$ century (Grygiel and Kleparski 2007). Among other things, it introduces an aspect of language use, namely that speakers of natural languages use inferences in communication. The approach is mainly characterised as a cognitive model of pragmatics because its mechanism involves processes of reasoning, mental projection, association, focussing on salient issues and inferencing. The key notion of inferencing amounts to saying that the word develops an additional meaning referring to a concept that the original use of the word strongly implied. As a consequence, change does not originate within language, but in language use, that is in pragmatic factors external to language structure (Traugott and Dasher 2002).

The so-called Invited Inferencing Theory of Semantic Change (henceforth: IITSC) was formulated and developed by Elizabeth Traugott in a number of publications that appeared in the 1980s and 1990s (Traugott 1989, Traugott and König 1991, Traugott 1999, Traugott and Dasher 2002, Traugott 2004). Relying on the functional and contextual tradition, Traugott develops the widely recognised hypothesis that the chief driving force in the processes of semantic change, which she believes are regular, is pragmatics. It is understood that in the process of communication different pragmatic meanings may become salient in different communities. To a large extent, such differences depend on the context in which the new meanings are primarily exploited. The prime objective of IITSC is to account for the conventionalisation of pragmatic meanings and their reanalysis as semantic meanings. Inferences that arise in specific contexts can come to be reanalysed as part of the conventional meaning associated with a given construction. Inferences of this kind are invited in the sense that they are frequently suggested by the context. 
According to Traugott's IITSC, the process of semantic change begins when a linguistic unit, used in a specific context, gives rise to an invited inference. An invited inference is a 'particularized conversational implicature', i.e. a communicated proposition whose meaning is context-dependent rather than derived directly from the encoded information in the utterance/text. An important characteristic of invited inferences is that they "are not stably associated with any linguistic form" (Traugott 2004: 547). The invited inferences that contribute to semantic change arise when the speaker/writer formulates his/her utterance/text in such a way that the addressee/reader feels invited to draw a particular inference, thereby ensuring that what is implied is understood as being part of what is communicated.

If a construction gives rise to the same invited inference often enough in a specific kind of context, it may become a generalized invited inference. As these inferences become "widely understood, and often exploited" (Traugott and Dasher 2002: 33), they may become conventionalized, and the inference formerly associated with a particular word will become part of its encoded meaning, or semantics. At this point, the pragmatically adjusted lexical item may be ambiguous between its original meaning and the newly developed meaning, or the original meaning may eventually be lost. In either case, when the new meaning is recovered, it is no longer cancellable and a semantic change becomes permanent. Thus, lexical adjustment may be a one-off process, used once and then forgotten, creating an ad hoc concept tied to a particular context that may never occur again. However, some of these pragmatically constructed senses may catch on in the communicative interactions of a few people or a group, and so become regularly and frequently used. In such cases, the pragmatic process of concept construction becomes progressively more conventionalized, and may ultimately spread through a speech community and stabilize as an extra lexical sense.

As a result of invited inferences, the meanings of words are frequently pragmatically adjusted and fine-tuned in context, so that their contribution to the proposition expressed is different from their lexically encoded sense. Wellknown examples include lexical narrowing (e.g. drink used to designate 'alcoholic drink'), widening (e.g. Kleenex used in the sense of 'soft facial tissue') and metaphorical extension (e.g. bulldozer used to mean 'forceful person'). ${ }^{2}$

It follows that semantic change can only arise in the process of speakerhearer interaction and is thus always the result of context-dependent alteration of usage. According to the principles of the IITSC, the speaker does the work of innovation but rather invites the hearer to infer his/her motivations behind the altered usage from context. One may speak of two interacting and inseparable levels to the communicative process, that is a linguistic level and pragmatic

\footnotetext{
${ }^{2}$ For more examples of lexical narrowing and widening in the history of English see Grygiel and Kleparski (2007).
} 
level. On the linguistic level, the speaker faces the question of which expressions have the semantic structure appropriate for conveying the ideas that he/she wishes to communicate. On the pragmatic level, the language user decides which expression is the best for his/her communicative purposes. When none of the conventional semantic structures are deemed appropriate, the speaker resorts to the modification of these structures - most of the time unconsciously. Thus, with regard to the communicative process, ways of novel usage, such as metonymy and metaphor for example, are merely pragmatic devices for altering usage within a conventionalised system.

Traugott (1989) reviews a range of instances of semantic change which she identifies as increases in expressed subjectivity, stemming from an informativeness strengthening inference, including developments in the English modals shall, must and will, speech act verbs such as insist and suggest, and adverbs such as probably, apparently and evidently. Observing that the semantic developments of these lexical items increase "coding of speaker informativeness about his or her attitude" (Traugott 1989:49), the author attributes the changes to the process of conventionalisation of implicatures, which strengthen both relevance and informativeness.

In addition, the model proposed by the author provides a partial explanation for the widespread regularities that occur in semantic change. They include development of meanings from 1) clause-internal to clausal and then sentential scope, 2) referential, truth-conditional, or 'content' to non-referential ('procedural') meanings, 3) relatively objective to subjective and then intersubjective meanings, 4) non-linguistic to linguistic meanings. The body of illustrative examples includes the development of epistemic modals, for example must (<'be fitting'), discourse markers, for example actually $(<$ manner adverb 'effectively'), performative uses of verbs, for example promise (< Lat. pro 'forward' + mis- 'sent').

\section{A ReleVANCE THEORY PERSPECTIVE ON SEMANTIC CHANGE}

An alternative account of semantic change by means of inferencing is offered in Relevance Theory. Relevance Theory questions the need for a separate category of generalized conversational implicature, and instead distinguishes conversational implicatures from inferences, which contribute to explicatures, i.e. propositions derived from the linguistic meaning of an utterance through a process of pragmatic enrichment. Relevance-theoretic accounts of semantic change focus on the inferential processes of utterance interpretation, with a consequent emphasis on the role of the addressee rather than the speaker (Nicolle 2011). Relevance Theory treats lexical narrowing and broadening, like utterance interpretation in general, as guided by expectations of relevance. 
Relevance is defined as a property of utterances and other inputs to cognitive processes (e.g. external stimuli such as sights and sounds, and internal representations such as thoughts, memories or conclusions of inferences). An input is relevant to an individual when it connects with available contextual assumptions to yield positive cognitive effects (e.g. true contextual implications, warranted strengthening or revisions of existing assumptions). Both narrowing and broadening emerge as by-products of the search for relevance, and the same encoded concept may be narrowed or broadened (or both) to different degrees and in different ways across different occasions of use.

A concept related to invited inferencing is 'context-induced reinterpretation' (e.g. Heine et al. 1991). As the term suggests, on this view more attention is paid to outcomes of change (reinterpretation) than to onsets of semantic change, and to the hearer than to the speaker. Heine, et al. (1991) discuss a number of semantic changes that seem to exhibit the same pattern accumulated shifts in meaning, initially inferential, may emerge as metaphorical shifts when they cross the boundaries of conceptual domains. This is illustrated with the development of the Ewe noun ví '(human) child' into a suffix with various senses emerging in different contexts. ${ }^{3}$ The cognitive concept CHILD contains, among others, the features YOUNG, SMALL and DESCENDANT OF, each of which may become the most salient content of the word child in different contexts of use, as illustrated in the following sentences:

1) If he was born in 1905, then he was still a child when the war began. YOUNG

2) This is a child's cello. SMALL

3) She is their only child. DESCENDANT OF

The Ewe examples given below, taken from Heine, et al. (1991), aim to show how these inferable peripheral senses may give rise to new conventional meanings in particular contexts of compounding or affixation.

YOUNG

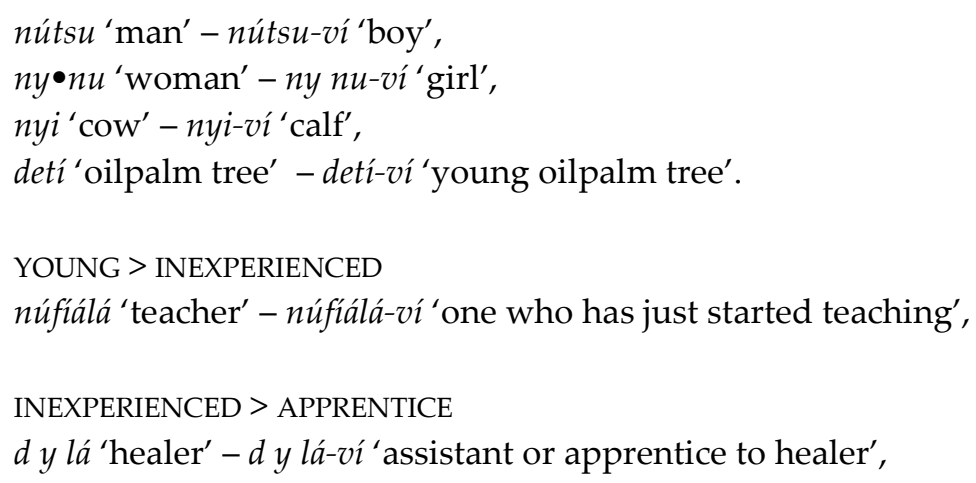

\footnotetext{
${ }^{3}$ Ewe is a Niger-Congo language spoken in West Africa (Ghana, Togo and Benin) in the so called Eweland which used to be part of the former Slave Region.
} 


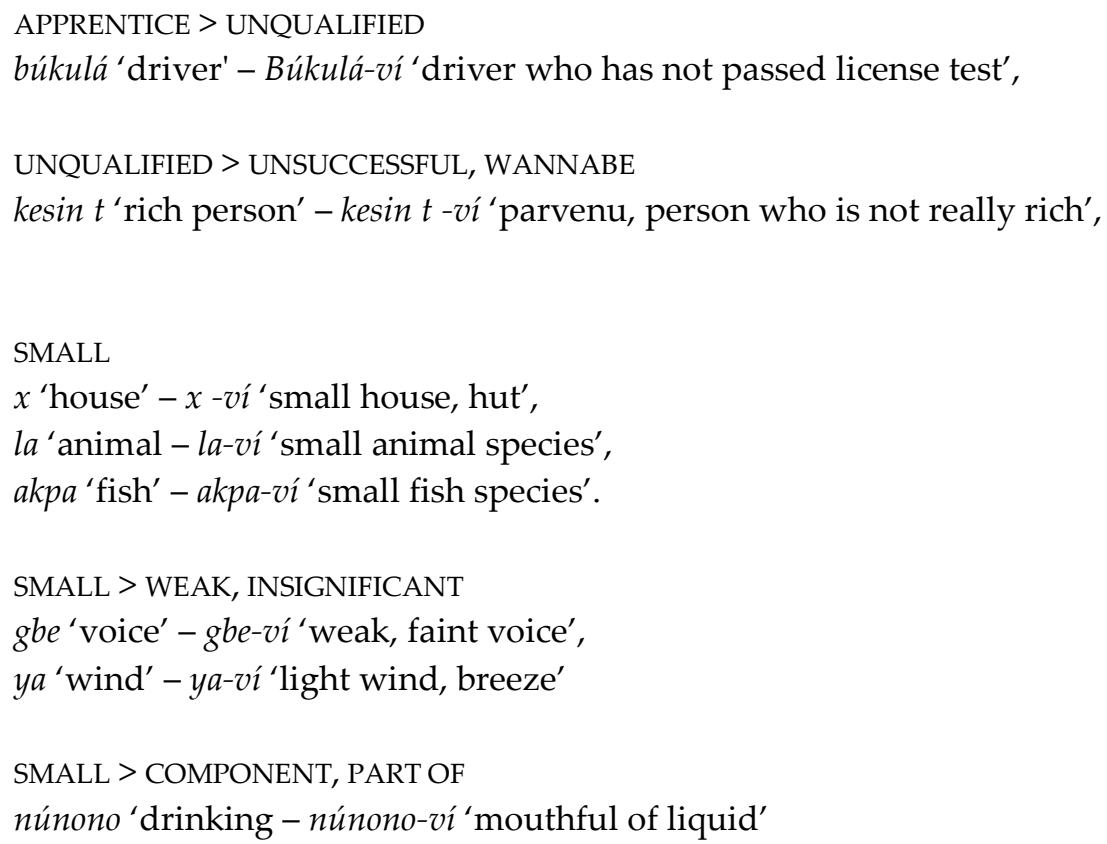

Apparently, chains of meaning shifts such as 'child' > 'young' > 'inexperienced' > 'apprentice' > 'unqualified' > 'unsuccessful' and 'child' > 'small' > 'component, part of' are all composed of tiny inferential steps plausibly attributed to implicature. Note that ultimately they can be classed as metonymic inferences, so long as properties shared by a conceptual entity, or elements co-occurring in a conceptual schema, can be classed as contiguous. Moreover, such shifts appear to be metonymic in that sense substitution is involved. For example, the -ví suffix meaning either 'young' or 'small' is not required to denote a human, unlike the original word. Heine, et al. (1991) identify the individual steps in the chain as metonymic, but apparently on the grounds, adopted directly from Traugott and König (1991), that implicature is metonymic, and not on the grounds of substitution of contiguous senses. More distant links in a chain such as 'child': 'unqualified' or 'child': 'component, part of' appear to be analogically related and taken in isolation, present as metaphors. Accordingly, Heine, et al. (1991) propose that implicature/inference and metonymy operate at the microlevel of change, producing over time what they term 'emerging metaphors' at the macrolevel.

\section{Pragmatic inferencing in the Case OF The Semantic Change Man/Male Human BeING $><$ HuSBand/Male SPOUSE}

It seems that most words for 'man' can be also used in the sense of 'husband' and vice versa. Both meanings co-exist at the synchronic level and their use can be only determined by context or a kind of tacit negotiation between the speakers during the course of interaction. Similarly, as shown in Grygiel (2008), 
various historical near-synonyms of man have acquired at some point of their semantic evolution the sense 'husband'. In English, the process can be observed in the sense alterations of lexical items such as, for example, mate or fellow. In addition, DSSPIL notes that words for 'husband' are most commonly formed out of those originally meaning 'man'. On the other hand, DSSPIL claims that probably in every I.E. language the word for 'man' may be used for 'husband' at least in colloquial or vulgar speech, as it is true even in Mod. E. 'my man'. Beyond doubt, the fact clearly gives additional evidence to the bi-directionality of semantic change and its pragmatic conditioning.

Also, the data from other languages seems to indicate that there are close ties between the conceptual domains MAN/MALE HUMAN BEING and HUSBAND/MALE SPOUSE. For example, the Polish counterpart of Mod.E. husband is mąz and in O. Pol. its original meaning was 'man' whereas Serbian muž, just like Dutch and Swedish man may refer to both 'man' and 'husband'. To take another example, Spanish marido derives from Lat. maritus 'husband', which originated from Lat. mas/maris 'man, male'. Notice also that the meaning 'husband' was developed by Latvian virs clearly related to Lat. vir 'man, husband, hero, warrior, soldier'.

We may hypothesise that the shift in meaning originates in a singular event where the speaker sets up a frame of reference in which the conceptual domain HUSBAND/MALE SPOUSE and the lexical item associated with it is projected onto the conceptual domain MAN/MALE HUMAN BEING. Because of these inferences, a new sense becomes invited. The semantic structure of the newly emerged sense thread develops a structure of its own although sharing many of its conceptual elements with the input spaces from which it was integrated. The hybrid may continue its evolution in the direction of the target domain and - with the passage of time - its semantic structure becomes fully entrenched within the new concept. It seems that the process is possible because the speaker conceptualises the entities in the current frame of reference as comparable and integrates them into one.

Since the two conceptual domains, that is HUSBAND/MALE SPOUSE and MAN/MALE HUMAN BEING, seem to be closely related conceptually, their integration is a natural consequence of overlapping semantic structures. Notice that being a husband presupposes being a man and every unmarried man can be perceived as a potential husband. Notice that this semantic change is a gradual process where one entity is conceptualised in terms of another. It starts at the pragmatic level where it assumes the form of inferencing and its conventionalisation may take place in several stages. As a result, one can hardly draw any sharp distinction between the ad hoc usage of a word in a new meaning and polysemy, on the one hand, and partial and full semantic change, on the other. Therefore, many near-synonyms of man may only contextually be 
used in the sense 'husband', e.g. Mod. Pol. mężczyzna 'man, male human being' may be on some occasions contextually applied to 'husband'. ${ }^{4}$ In some cases the two meanings are complementary, e.g. Lat. vir, Mod. G. Mann, meaning both 'man, male human being' and 'husband', while in others one of the senses can only be traced in the word's etymology, e.g. O. N. verr 'husband' and Russian муж [muž] 'husband'.

In this context, the question arises why a process that starts as such a subjective, context-induced and ephemeral phenomenon should be so widespread across languages. The answer to the problem seems to be ultimately grounded in human cognition and, therefore, the panchronic dimension of the semantic change can only be explained with reference to the cognitive processes taking place in our minds irrespective of time and place. As indicated by Traugott and Dasher (2002: 25), the implicatures/inferences causing polysemisation and leading to semantic change are "both cognitive (information-related) and communicative/rhetorical (arising out of purposeful negotiation between speaker and addressee)".

The O.E. wer/were is a cognate with the Lat. vir and both lexical items O.E. wer and Lat. vir - are primarily associated with the sense thread 'man, male human being'. As shown by the quotations below, the O.E. wer often occurs next to wif 'woman' which proves its central position as an O.E. synonym of man. The O.E. wer is also related to O.Fris., O.Sax., O.H.G. wer, O.N. and O.N. verr, Goth. wair, O.Ir. fer (Gaelic fear), Lithuanian vyras, Skt. vira 'man, hero'. The O.E. wer used in the sense 'man, male human being' can be illustrated with the following citations extracted from the $O E D$ :

c900 zif oxa ofhnite wer oððe wif.

c1250 And on ðe sexte hundred zer Wimmen welten weres mester.

Although the second context given above is the last attestation of wer/were in the original meaning 'man, male human being', the remnants of the sense can still be traced in some compounds such as, for example, Mod.E. werewolf 'man who was capable of transforming himself into a wolf', were-jaguar 'in Olmec mythology, a creature partly human and partly feline', and also wergeld, whose last attestation comes from the late $19^{\text {th }}$ century, meaning the price set upon a man according to his rank, paid by way of compensation or fine in cases of homicide and certain other crimes to free the offender from further obligation or punishment.' In most of the compounds, however, such as wer-had 'male sex', wer-ðeod 'nation', werbeam 'warrior', folcwer 'man', wer was either replaced by man in the Mid.E. period or the form disappeared entirely.

Another meaning developed by wer/were -'husband' - appears at the same time as 'man' which prompts that the two senses were interrelated. The

\footnotetext{
${ }^{4}$ For example, in the context of this Polish sentence: Mój mężczyzna wyjechał do pracy w Chicago. 'My man/husband has gone to work in Chicago'.
} 
meaning 'husband' is also well documented in the $O E D$, for example in the following historical material:

c893 Heora wif..sædon..hie him woldon oðerra wera ceosan.

c1275 Go and clepe bine were and cumeb hider y-mene.

Historical evidence shows that the word wer/were functioned as the most important lexical item to express the sense 'husband' until it was replaced by the borrowing from O.N. husbondi 'master of the house'. Blair (1956) accounts for the lexical change by the fact that when the Norsemen settled in AngloSaxon England, they would often take Anglo-Saxon women as their wives. It was then only natural to refer to the husband using the Norse form for the concept meant, and to refer to the wife with her Anglo-Saxon designation, wif 'woman, wife'.

The use of wer/were in the sense 'husband' is also attested by the semantics of some morphologically related O.E. derivatives such as, for example, werleas 'without a husband' or werlic 'marital'. In the O.E. alliterative poetry, on the other hand, wer acquires the sense 'hero, warrior' which can be interpreted as a natural consequence of the conceptual overlapping between the conceptual domains MAN/MALE HUMAN BEING and WARRIOR/SOLDIER. The conceptual ties between the two domains can be additionally illustrated with the related collective noun wered which, according to $C A S D$, developed the sense 'band, company, throng, multitude', but also the specific 'army, troop, legion'. 5

Likewise, the etymology of Mid.E. heme seems to be parallel in many respects to the semantic history of husband. The word heme is derived from the O.E. ham 'home' and its original meaning was 'householder' before it became generalised and started to be applied in the sense 'man, male human being' which may be illustrated with the following OED quotations:

a1250 For children gromes heme and hine $\mathrm{Hi}$ bencheb alle of bire pine.

a1327 An heme in an herygoud with honginde sleven.

Mod. E. husband, on the other hand, continues the late O.E. form husbonda, where hus means 'house' and the meaning of bonda, a cognate of O.N. bondi, is presented in the $O E D$ as 'peasant owning his own house and land, freeholder, franklin, yeoman'. Hence, the original meaning of husband was 'the master of a house, the male head of a household' which is shown in the following OED material:

c1000 Ne sitte ze on bam fyrme stan setlum be læs be..se husbonda [Hatton MS. husb unde] hate be arisan.

a1240 pe husebonde, bat is wit, warneð his hus.

\footnotetext{
${ }^{5}$ This may be evidenced by the following OED quotations:

971 Ac se heabrym bæs Godes hades bæm englicum weorodum simle ondweard wæs.

c1000 Ealle bas bing se hælend spræc mid biz-spellum to bamweredum.
} 
Another sense of husband, that links the word to the conceptual domain OCCUPATION/PROFESSION, developed in the Mid. E. period when the word was used to refer to 'cultivator, tiller, farmer, husbandman' as demonstrated in the $O E D$ illustrative quotations:

c1220 Fox is hire to name...husebondes hire haten, for hire harm dedes.

c1330 Do com..burgeis \& merchant, \& knyght \& squiere..hosbond \& sergant, \& tak of bam homage.

Also, the OED provides evidence that husband was used in the sense 'manager' and the verb to husband acquired the meaning 'to direct and manage with frugality' ${ }^{6}$

\section{SEMANTIC CHANGE AS A SHIFT IN CONTEXTUALISATION}

Meaning variation may result, or - to put it more adequately - primarily does result from the inherent properties of meaning itself such as plasticity, flexibility and context-dependency, which are caused by semantic underspecification, or the fact that the full semantic potential of a lexical item is never made use of. Consequently, the meaning of a word varies depending on the context or - to put it differently - becomes contextually flexible and depends on the hearer's interpretation. Take, for example, the sentence Johnny's a good reader that means one thing in a first grade schoolroom, but quite another reading is imposed by the context of a fifth grade schoolroom and understandably - something utterly different in a school of declamation. Similarly, a given linguistic form may call forth different responses from different hearers involved in the process of communication. A description of good food may make a healthy and hungry man say Splendid! while a dyspeptic may say How unpleasant! and one who has just eaten his meal may refrain from saying anything at all.

When various contextualisations of the lexical item goldenrod are analysed, one can see that the word means one thing to an artist, another to a careful farmer and still another to a hay-fever patient. All of them pay attention to different kinds of context-induced inferences. To take a somewhat more complex case, notice that the word shoe tends to mean one thing to a labourer, or to a soldier, and something entirely different to a dancer; one thing to a man and another to a woman, one thing to a mender of shoes and another to the owner of a shoe factory, something else to the operator of shoe-making machinery or to a retail salesman. In more technical terms, from the meaning

6 The use is illustrated with the following OED quotations: 1545 A good grounde..well husbanded bringeth out great plentie of byg eared corn.

1586 That his majesties..revenues [be] well husbanded and looked unto. 
potential of a word like horse, through different kinds of contextualisations we caneither activate the image of a 'prototypical horse', or an 'ideal horse', or an image of what is known as a 'stereotypical horse'. The three cases of shifts in contextualisation mentioned here are all examples of operations that can be triggered by a single word. Nevertheless, these nuances of meaning are in no way confined to any of the classes named. Thus, both farmers and victims of hay fever may look at goldenrod in the artistic way. Similarly, soldiers or labourers may observe the shoes of a professional dancer and some males may be as much interested in women's shoes as the women themselves. Apart from this, meaning underspecification or vagueness ${ }^{7}$ may also lead to shifts in semantic emphasis and - as the result of this - bring about semantic change. And so, Mod. E. knave - a cognate of Mod. G. Knabe - continues O.E. cnapa/cnafa 'male child, boy', as shown in the following OED quotations:

a1050 $\mathrm{Na}$ zedafenað bam se to fulfremednysse hozað, gamenian mid cnafan [L. cum pa rvulo].

1000 Syle mihte cnafan binum [L. puero tuo].

The fact that boys frequently entered the service of a lord or master gives an extralinguistic explanation for the following development which took place in the O.E. and Mid. E. period 'boy' > 'boy servant' > 'servant irrespective of age'. In other words, many boys, especially those of low condition, were employed as servants and the emphasis on this nuance of the basic meaning in the form of an invited inference rendered the word a new sense 'servant' evidenced in the following Mid. E. language material quoted after the $O E D$ :

a1225 pe kokes knaue, bet wassheð be disshes iðe kuchene.

a1300 He bad cum wit him knaues tua.

Again, in terms of extralingustic conditions servants and serfs do not necessarily like the treatment meted out to them by their masters and, therefore, they either act in a way that their masters perceive as insolent or - in extreme cases - some servants take to deceitful and dishonourable practices and become rascals. In the $13^{\text {th }}$ century, there appears a new sense of knave which, compared to the earlier 'servant irrespective of age', shows a further strengthening of the

7 For Waldron (1979) broadly-understood vagueness is considered as one of the most important conditions of changes in meaning. The author distinguishes several types of vagueness. One is ambiguity, where there is some hesitation on the part of the interpreter between two or more meanings of a lexical item. The next type, viz., generality, is characteristic of those things, acts and facts which have very few limiting criteria and are therefore wide in application, for example, case, huge, thing. Another type of semantic vagueness is variation among different speakers as to the precise definition of certain lexical items. This holds particularly true of moral and political terms such as justice, wicked, right, etc. Finally, Waldron names indeterminacy. What is meant here is the fact that no decision has ever been taken as to the precise limits of application of such terms as shoulder, morning, evening and normally no one feels it to be necessary to specify such limits. 
pejorative load, from socially negatively tinted 'servant' to morally disreputable 'base and crafty rogue'. Again, one could say that the emphasis put on that part of the word's semantic structure, generated as an inference, was responsible for the rise of the present-day meaning of knave. ${ }^{8}$

\section{CONCLUSION}

Meaning is always in flux. The semantic development of the lexical items discussed above shows that the boundary line between the conventionalised sense alteration and polysemy is vague and the meaning variation is to be treated as a timeless phenomenon initiated by pragmatic devices such as inferencing. In all the examples of invited inferencing cited here the claim is that the chief cognitive mechanisms underlying the changes include conceptual metaphors, metonymy as well as conceptual blending. Thus, Traugott's IITSC fully corresponds to Fauconnier and Turner's (2002: 321) idea of brain as "a bubble chamber of mental spaces" where meaning receives various contextual configurations. The interconnectedness of conceptual domains and the ease with which particular words change their meaning from, for example, 'man' to 'husband', 'warrior' to 'man' or 'hero', proves that mental spaces are formed all the time from old ones and inferences are constantly being generated from new contexts. The prototypicality of some patterns of semantic change, like those sketched in this study, stems from the fact that meaning transformations are pragmatically driven and cognitively verifiable and - as such - are universally grounded in human experience.

\section{BIBLIOGRAPHY}

BRÉAL, M. (1921 [1897]), Essai de sémantique. Science de significations, Paris, Hachette. FAUCONNIER, G. (1997), Mappings in Thought and Language, Cambridge, Cambridge University Press.

Fauconnier, G. AND Turner, M. (2002), The Way We Think: Conceptual Blending and the Mind's Hidden Complexities, New York, Basic Books.

FRITZ, G. (1998), Historische Semantik, Stuttgart, Metzler.

GEIS, M. L. (1982), The Language of Television Advertising, New York/London, Academic Press.

GRAESSER, A. C. et al. (2001), "Constructing inferences and relations during text comprehension", in Text Representation: Linguistic and Psychological Aspects, Sanders, T. et al. (eds.), Amsterdam/Philadelphia, John Benjamins, 249-273.

\footnotetext{
${ }^{8}$ As shown in Kleparski (1988), English varlet, ribald, blackguard and flunkey represent a similar line of development. For instance, the word varlet originally in the $15^{\text {th }}$ century was used in the sense 'servant, attendant' before it developed a novel meaning 'rogue, knave' a century later.
} 
Grygiel, M. AND KlePARSKI, G. A. (2007), Main Trends in Historical Semantics, Rzeszów, Wydawnictwo UR.

GRYGIEL, M. (2004), "Semantic change as a process of conceptual blending”, in Annual Review of Cognitive Linguistics 2, Ruiz de Mendoza, F. J. (ed.), Amsterdam/Philadelphia, John Benjamins, 285-304.

Grygiel, M. (2008), From Semantic Change to Conceptual Blending: Semantic Development of English Historical Near-synonyms of MAN/MALE HUMAN BEING, Rzeszów, Wydawnictwo UR.

GrygIEL, M. (2012), In Search of a Cognitive Linguistic Model of Semantic Change, Saarbrücken, Lambert Academic Publishing.

HeINE, B. et al. (1991), Grammaticalization: A Conceptual Framework, Chicago, Univerity of Chicago Press.

KlePARSKI, G. A. (1988), Semantic Change and Semantic Components: A Study of English Evaluative Developments in the Domain of HUMANS, The Catholic University of Lublin, Unpublished PhD dissertation.

LAMBRECHT, K. (1994), Information Structure and Sentence Form, Cambridge, Cambridge University Press.

LeVINSON, S. (1983), Pragmatics, Cambridge, Cambridge University Press.

LEWANDOWSKA-TOMASZCZYK, B. (1985), “On semantic change in a dynamic model of language", in Historical Semantics: Historical Word-formation, Fisiak, J. (ed.), Berlin, Mouton de Gruyter, 297-323.

NiCOLLE, S. (2011), "Pragmatic aspects of grammaticalization", in The Oxford Handbook of Grammaticalization, Heine, B. and Narrog, H. (eds.), Oxford, Oxford University Press, 401-412.

SPERBER, D. AND WILSON, D. (1986), Relevance: Communication and Cognition, Oxford, Blackwell.

TraugotT, E. C. AND DASHER, R. B. (2002), Regularity in Semantic Change, Cambridge, Cambridge University Press.

TRAUGOTT, E. C. (1985), "On regularity in semantic change", in Journal of Literary Semantics, vol. 14, 155-173.

TRAUGOTT, E. C. (1989), “On the rise of epistemic meanings in English: An example of subjectification in semantic change", Language, 65, 31-55.

TRAUGOTT, E.C. AND KÖNIG, E. (1991), "The semantics-pragmatics of grammaticalization revisited", in Approaches to Grammaticalization, Traugott, E. C. \& Heine, B. (eds.), vol. 1, Amsterdam, John Benjamins, 189-218.

TRAUGOTT, E. C. (1999), "The role of pragmatics in a theory of semantic change", in Pragmatics in 1998: Selected Papers from the Sixth International Pragmatics Conference, II, Verschueren, J. (ed.), Antwerp, International Pragmatics Association, 93-102.

TRAugOTT, E. C. (2004), "Historical pragmatics", in Handbook of Pragmatics, Horn, L.R. \& Ward, G. (eds.), Oxford, Blackwell, 538-561.

WALDRON, R.A. (1979), Sense and Sense Development, London, Andre Deutsch (2 ${ }^{\text {nd }}$ edition). 


\section{DICTIONARIES}

A Concise Anglo-Saxon Dictionary (2002) Clark Hall, J.R. Toronto: University of Toronto Press.

A Dictionary of Selected Synonyms in the Principal Indo-European Languages (1949) Buck, C.D. Chicago/London: The University of Chicago Press.

The Oxford English Dictionary (1972-1976) Murray, J., Ch.T. Onions, W. Craige and F.J. Furnivall (eds.). Oxford: Oxford University Press. 